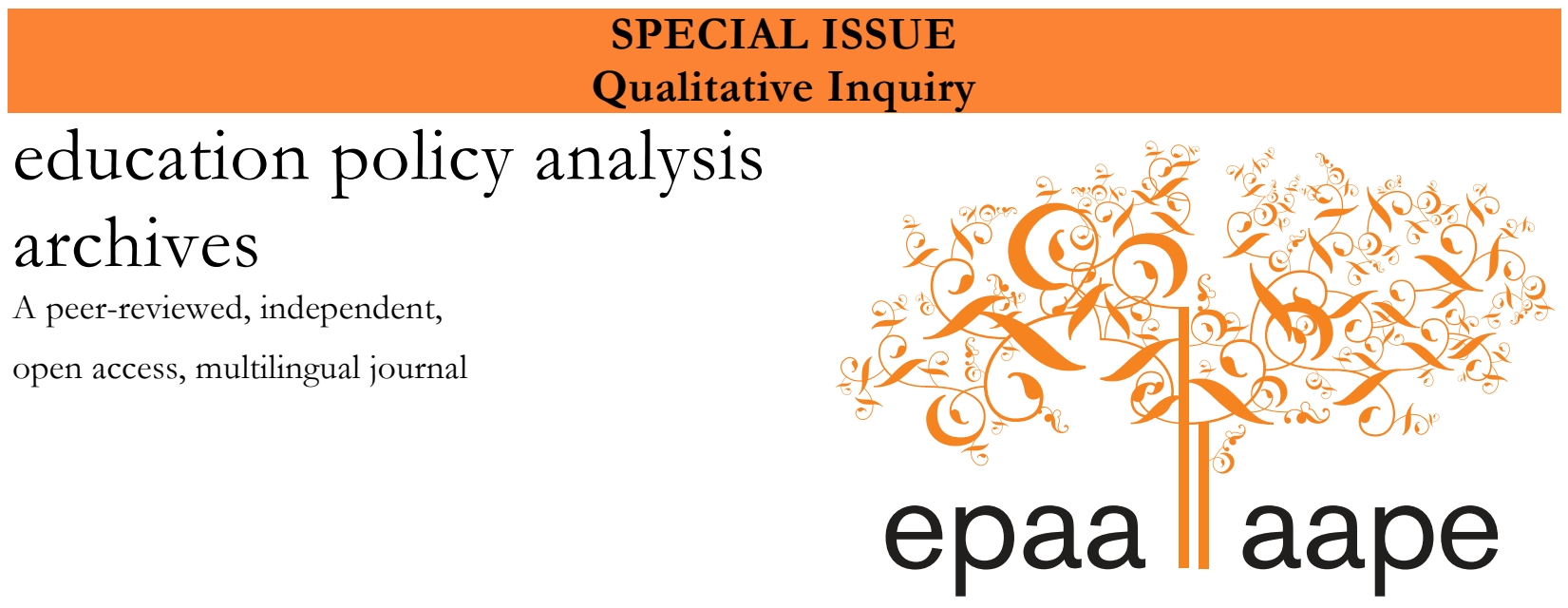

Arizona State University

Volume 22 Number $11 \quad$ February $17^{\text {th }}, 2014$

ISSN 1068-2341

\title{
Qualitative Research as Policy Knowledge: Framing Policy Problems and Transforming Education from the Ground Up
}

\author{
Michael J. Dumas \\ \& \\ Gary Anderson \\ New York University \\ United States of America
}

Citation: Dumas, M.J., \& Anderson, G. (2014). Qualitative research as policy knowledge: Framing policy problems and transforming education from the ground up. Education Policy Analysis Archives, 22 (11). http://dx.doi.org/10.14507/epaa.v22n11.2014. This article is part of EPAA/AAPE's Special Issue on Qualitative Inquiry.

Abstract: As educational research becomes privatized, commodified and commercialized, research relevance increasingly means being incorporated into neoliberal ideological and economic agendas. Within this social context, qualitative research in particular is often deemed less relevant (if not irrelevant) because it does not provide prescriptions for best practices or claim to offer "proof" that a given policy will lead to specific outcomes. The authors suggest that notions of research's relevance to policy and practice may be too narrow a way of thinking about how qualitative scholarship might enter policy discourse. Instead, they propose that scholars advance a new common sense, in which "policy knowledge" is understood as more useful-indeed, more relevant-than mere policy prescription. In their view, impacting the very framing of policy will require that scholars expand their notion of the audiences for educational research, and be more 
creative at reaching a diverse range of stakeholders, including not only policymakers, but also journalists, youth and community activists, and teachers.

Keywords: Qualitative research, educational policy, politics of education

\section{La investigación cualitativa como conocimiento político: Enmarcando problemas de política y de transformación de la educación desde la base}

Resumen: A medida que la investigación educativa se privatiza, mercantiliza y comercializa la relevancia de la investigación significa cada vez más estar incorporado en las agendas ideológicas y económicas neoliberales. Dentro de este contexto social, la investigación cualitativa, en particular, a menudo se considera menos relevante (si no irrelevante) ya que no proporciona recetas para mejores prácticas o no presentar " pruebas" de que una determinada política conducirá a resultados específicos. Los autores sugieren que las nociones de relevancia de la investigación para las políticas y prácticas educativas pueden ser una manera demasiado estrecha para pensar acerca de cómo los estudios cualitativos podrían entrar en el discurso político En su lugar, proponen que los estudiosos avancen un nuevo sentido común, en el que se entiende "conocimiento político", como más útil -de hecho, más relevante que la mera prescripción política. En nuestra opinión, influir en la propia formulación de políticas, requiere necesario que los investigadores amplíen la noción de las audiencias interesadas en la investigación educativa y ser más creativos para alcanzar una amplia gama de públicos interesados, incluyendo no sólo políticos, sino también periodistas, jóvenes, activistas de la comunidad, y docentes.

Palabras clave: investigación cualitativa; política educativa; política de la educación.

\section{A pesquisa qualitativa como conhecimento político: Enquadrando problemas de política e transformando a educação a partir da base}

Resumo Enquanto a pesquisa educacional é privatizada, mercantilizada e comercializada a relevância da pesquisa significa cada vez mais sendo incorporadas às agendas ideológicas e econômicas neoliberais. Dentro deste contexto social, a pesquisa qualitativa, em particular, é muitas vezes considerada menos relevante (se não irrelevante), pois ele não fornece receitas para determinas as melhores práticas ou não apresentar" provas" de que uma determinada política levará a resultados específicos. Os autores sugerem que as noções de relevância da pesquisa para as políticas e práticas educacionais podem ser uma maneira demasiado estreita de pensar sobre como estudos qualitativos poderia entrar no discurso político Ao invés disso, nos propomos que os pesquisadores desenvolvam um novo senso comum, em que "o conhecimento político " possa ser mais útil, e na verdade, mais importante do que a mera regulação política . Em nossa opinião, influenciar a política em si, exige que os pesquisadores expandam a noção de público interessado na pesquisa educacional e ser mais criativos para atingir uma ampla gama de públicos interessados, , incluindo não só políticos, mas também jornalistas, juventude, ativistas comunitários e professores. Palavras-chave: pesquisa qualitativa, a política de educação, a política de educação.

\section{Introduction}

The paradigm wars (Anderson \& Herr, 1999; Gage, 1989) have dissipated, and "objectivityseeking quantitative researchers," whom Gage claimed were under attack from qualitative and critical researchers, were ultimately declared winners in the wake of the 2002 National Research Council (NRC) report, Scientific Research in Education. Meanwhile, quantitative and qualitative academic researchers have retired to their respective corners (e.g., AERA divisions, special interest groups, specialized conferences and journals) and proceeded to largely ignore one another, with the 
exception of some attempts that sought a middle ground, such as attempts to blur the boundary (Ercikan \& Roth, 2006) or utilize mixed methods ${ }^{1}$. These battles within the academy have generated much heat because they impact status, careers, and funding; outside the academy, they are largely viewed as irrelevant.

While educational researchers from the social sciences and the humanities continue to produce various genres of qualitative scholarship in the academy, some are concerned about the ability of this research to guide policymakers and educational practitioners in matters of policy, pedagogy, and practice. Some researchers have characterized the gap between scholars and policymakers or practitioners as reflecting separate cultures (Ginsberg \& Gorostiaga, 2001). Within the dominant policy paradigm, relevance outside the academy requires that educational policy research: 1) clearly identify how specific policies contribute to, or impede, academic achievement, organizational efficiency, or delivery of services; 2) offer "proof" or "evidence" of "best practices" in educational policy formation and implementation; and/or 3) assess the outcomes of specific policy interventions, with attention to cost-benefit analyses. Within this dominant paradigm, the aim of educational policy research-its claim to relevance-rests in its ability to inform local, state, and federal policy and institutional decision-making. There is a bias within such a paradigm for quantification and large numbers. Even qualitative case study research tends to sacrifice depth in favor of multiple cases, even when it means shallow data within each site. Instead of seeing this as a trade off between depth and breadth, more cases are typically required by funders who tend to be uncomfortable with single case studies.

Policy debates from the bilingual education and reading "wars" of the 1990s through to more recent debates over charter schools and high stakes accountability are fought out largely on the terrain of quantitative research. For example, pre-NCLB debates about Texas Accountability were fought largely over quantitative research studies (Carnoy, Loeb, \& Smith, 2000; Haney, 2000; Klein, Hamilton, McCaffrey, \& Stecher, 2000) and continue to be today (Vazquez-Heilig \& DarlingHammond, 2008). More recently, dueling quantitative studies from Stanford (Center for Research on Education Outcomes, 2009) and Harvard (Hoxby, 2004) have attempted to frame the academic debate on charter schools. Policy advocates routinely tout the results of single studies as definitive, a tendency that began with the Coleman Report of the 1960s.

However, while academics, advocates and, increasingly, bloggers sometimes cite these quantitative studies, it is not clear to what extent even these studies influence policy at the problem definition stage or later stages of the policy process. For instance, market-based reforms emerged and continue to move ahead with little research-based warrant. More recently, Race to the Top policies promoting value added and growth models for high stakes teacher and principal evaluation are moving ahead even while most quantitative researchers question their internal validity and virtually all question their consequential validity. (Amrein-Beardsley, 2008; Darling Hammond, Amrien-Beardsley, Haertel \& Rothstein, 2011). In spite of a new discourse of "evidence-based" policy and practice, current school reform policies are more ideology-based than research-based (Shaker\& Heilman, 2004). Wiseman (2010) suggests that the global policy convergence toward evidence-based policy-making may have more to do with gaining legitimacy than the actual use of evidence to make policy ${ }^{2}$.

While it is not clear that even quantitative researchers are influencing education policy in any

\footnotetext{
${ }^{1}$ While the notion of doing mixed methods appears to resolve the quantitative/qualitative binary, this often turns out to be subjugating one methodology to the logic of another.

2 Some have argued that not only does quantitative research not influence policy, but that quantification and numbers are a new form of neoliberal "governing knowledge"; that is, knowledge of a new kind - a regime of numbers - that constitutes a 'resource through which surveillance can be exercised' (Ozga, 2008, p. 264).
} 
direct way, it is clear to most academic researchers that studies that do not provide quantifiable findings find themselves at an even greater disadvantage. This is particularly the case since the postNRC reassertion of scientism, which Lather (2004) called "a racialized masculinist backlash against the proliferation of research approaches that characterize the past 20 years of social inquiry" (p. 15).

Our goal in this paper is not to rehearse the epistemological and methodological debates of the last few decades in education. Rather, we want to explore what it might look like for qualitative scholarship_-defined broadly_to be influential in informing current policy debates and their implications for educational practice. Given its interpretive methodological approaches, its thick descriptions and nuanced findings, its lack of a statistical meta-analysis for knowledge accumulation, its goal of divergent complexity rather than convergent certainty, qualitative research is more susceptible than quantitative research to the critique that it is unable to address urgent educational policy priorities. Given the powerful new policy networks (e.g. think tanks, venture philanthropy, edubusinesses) successfully pushing current free-market and new managerialist ideologies (Scott, 2011; Ward, 2011), academic scholarship of all kinds is increasingly struggling with how it might enter into and impact the public conversation about school reform.

One strategy to address this lack of apparent relevance might be to circle the wagons and move qualitative research back toward its more positivist sociological (as opposed to anthropological) origins in the analytic induction methods of grounded theory (Glaser \& Strauss, 1967). However, we believe that expanding qualitative scholarship to incorporate a broader bandwidth of forms of knowledge production is a more promising direction. We also suggest that notions of research's "relevance" to policy and practice may be too narrow a way of thinking about how qualitative scholarship might enter policy discourse.

Therefore, we will first take on the notion of relevance and encourage scholars to put forward a more expansive kind of "relevance" that complicates the common-sense understanding of it described above. Part of rethinking relevance has to do with the recognition that influence is always indirect and diffuse and that its influence is most effectively exerted at the problem definition stage. As we better understand how problems are actually framed (Lakoff, 2008), we may be better equipped to enter the policy conversation.

The ability of qualitative researchers to frame problems and influence policy will become more difficult to the extent that educational research is increasingly being privatized, commodified and commercialized. According to Ball (2010), "higher education institutions are being displaced as knowledge brokers, and at the same time 'enterprised' and 'hybridised', in a new education policy knowledge market” (p. 124). Within this new social context, research relevance increasingly means being incorporated into broader ideological and economic agendas (St. Clair \& Belzer, 2007). This means that our scholarship increasingly becomes inseparable from and at the service of those who drive policy for their own ends. Thus, its relevance is built in.

Second, in addition to rethinking "relevance," we need to consider how we might think more clearly about what our research tells us_-not about "what works" - but about what we know. In the absence of statistical meta-analysis, how do qualitative researchers accumulate knowledge across studies in non-reductionist ways that can be shared with these audiences (Noblitt \& Hare, 1988), and perhaps more importantly, develop a new common sense in which stakeholders come to regard policy knowledge as more useful_-indeed, more relevant — than mere policy prescription?

Third, we need to expand our notion of our audiences and be more creative at reaching them. How do we better reach out to or collaborate with, not only policy-makers, but also education practitioners, journalists, policy advocates, social activists, and community organizers, all of whom are addressing education issues through new social media and networks. How do we learn to use print, electronic, and social media more effectively? 


\section{Dispensing with Fictions}

We may seem to be presenting an overly ambitious project, but we hope to build on past work on research relevance and qualitative scholarship, not rehash it. So we want to acknowledge that there are some issues that have been more or less resolved, but still exist as useful fictions. We want to dispense with these in order to move onto the agenda we have laid out above.

The first fiction is that problems are defined, and policy formulated and implemented, based on some more or less direct relationship between the results of scholarly research and policy-makers or practitioners. In fact, policy is more typically conceived and developed based on interest group politics, lobbyists, anecdote, "common sense," ideological grounds, profit motives, and other reasons that typically have little to do with research evidence or rational decision-making models (Anderson\& Donchik, 2013; Ball, 2010; Lakoff, 2008; Stone, 2001). This does not mean that scholarly knowledge has no influence, but that its influence is far more indirect than often thought.

The second fiction is that quantitative research is necessarily more "predictive," or "generalizable," or "valid," than other forms of scholarship. Labaree (2011) suggests that "educational research as a domain, with its focus on a radically soft and thoroughly applied form of knowledge and with its low academic standing, fits the pattern in which weak professions have been most likely to adopt quantification" (p. 621). Regardless of why the field of educational research tends to view quantification as more legitimate, as with all kinds of research, there are trade offs in doing quantitative or qualitative research (e.g. breadth vs. depth) and serious limitations for each. Achieving high levels of rigor in quantitative studies involves limitations that include social and cultural decontextualization, ahistoricity, the creation of randomization that is seldom generalizable to real life settings, and so on (Erickson \& Gutierrez, 2002; Donmoyer, 2012).

Finally, we need to disabuse ourselves of the fiction that the most important indicator of effective policy is related to quantifiable academic outcomes. Policies are also about educational inputs, processes and practices, non-cognitive phenomena, out-of-school factors, and facilitating meaningful human experiences in schools and in the communities they serve, and these can seldom be quantified without egregious levels of reductionism (Lincoln \& Guba, 1985; Verschuren, 2001)

\section{Rethinking Qualitative Scholarship and our Audiences}

There is a proliferation of policy actors seeking policy knowledge beyond the university. This not only includes policy-makers and education practitioners, but a plethora of advocacy organizations. Knowledge is also increasingly produced outside the university, both by non-profit organizations, practitioners, and communities, who are using various forms of action research. We believe that given the expansion of the need for policy knowledge and its production beyond the university, we need to broaden what counts as qualitative scholarship.

Given the qualitative nature of educational practice, one would expect qualitative research to be more relevant to educational practitioners. And yet, there is little evidence that it is widely read outside the academy. As Clandinin and Connelly (1995) put it,

Outsider knowledge is often experienced by teachers as a "rhetoric of conclusions"

which enters the practitioners' professional landscape through informational

conduits that funnel propositional and theoretical knowledge to them with little

understanding that their landscape is personal, contextual, subjective, temporal,

historical, and relational among people. (p. 42)

While action research has gained somewhat greater levels of attention among practitioners, it is not viewed as legitimate research in universities (Anderson \& Herr, 1999). Furthermore, within school 
districts, it has been largely appropriated by data utilization schemes and business-oriented notions of "data-driven decision-making" driven largely by test scores (Wayman \& Springfield, 2006).

More and more educational researchers are becoming "vendors" to school districts, but in

cases where a researcher's work has been used in schools and districts (e.g. Lucy Calkins, Charlotte Danielson, Robert Slavin, etc.) it tends to be "scaled up" in ways that too often gut it of its original effectiveness, or else it has to be implemented with such fidelity that it strips teachers of their professional judgment. The old paradigm of applied academic research, whether quantitative or qualitative, remains the same: that knowledge is created in universities, disseminated through journals, workshops, and consultancies, and implemented by practitioners. This paradigm has never worked well, and decades of implementation studies have not had much of an impact (Braun, Ball, Maguire \& Hoskins, 2011; Berman \& McLaughlin, 1978; Payne, 2008). It is time to reimagine the terrain of qualitative research.

In the last four decades there has been a proliferation of non-positivist scholarship in both the social sciences and the humanities. Our understanding of qualitative research incorporates a broad range of methodological approaches and stances, such as ethnography, ethnomethodology, auto-ethnography, hermeneutics, historiography, policy archeology and geneology, discourse analysis, cultural studies, narrative, self-study, investigative journalism, action research, and community-based participatory research. Outside the academy, community groups, teacher activists, and advocacy organizations are increasingly producing scholarship either in collaboration with or independent of academics. If qualitative research is defined more broadly, we believe it can be more useful, especially if we also redefine relevance and our audience. After all, policy doesn't always come from policy-makers; practitioners also make policy as they implement, adapt, influence, appropriate, modify, push back, and advocate for new policies (Weatherley \& Lipsky, 1977). Increasingly, organized communities are also influencing policy as they push back and demand policy changes (Scott \& Fruchter, 2009; Warren \& Mapp, 2011). In other words, policy can sometimes come from the ground up. That is, we may do just as well, if not better, thinking about using qualitative and participatory action research to impact policy by communicating directly with communities, families, teachers and young people_-and not simply, or perhaps even primarily, with policymakers (Anyon, 2005; Lipman, 2011).

\section{Redefining Relevance}

When one looks at the extent to which ideology trumps research in current educational reforms it is easy to think that educational research is irrelevant. But as we noted above, research has never informed educational policy in any simple way. How qualitative research in education is or is not used by policy-makers is related to the longstanding question of how social science research gets disseminated and utilized. Weiss (1977) argued optimistically in the 1970s that research was not taken up directly by policy-makers, but rather had what she called an illumination function at the problem definition stage through a process she termed percolation that resulted in a climate of informed opinion.

Evidence suggests that government officials use research less to arrive at solutions than to orient themselves to problems. They use research to help them think about issues and define the problematics of a situation, to gain new ideas and new perspectives. They use research to help formulate problems and to set the agenda for future policy actions. And much of this use is not deliberate, direct, and targeted, but a result of long-term percolation of social science concepts, theories, and findings into the climate of informed opinion. (p. 534)

Sometimes this climate of informed opinion has led to a misappropriation of the findings of 
qualitative research as it merges with our cultural biases. For example, Oscar Lewis's ethnographic accounts of the poor were often taken up by policy-makers as evidence of a culture of poverty and a need to intervene at the individual and cultural level to address poverty not as a structural problem, but rather as a cultural one. Lewis, who was a socialist, did not promote policies that blamed individuals and their cultures, but his research, which became widely read, percolated into the policy community in ways that provided an informed opinion about poverty that tended to view it as a cultural rather than a structural problem.

Another way of thinking about Weiss's view of knowledge dissemination is through the notion of policy framing, which has gained increased popularity, not only in terms of how social and educational problems are framed by policy-makers, but how the public responds to policies (Lakoff, 2008). William Julius Wilson, like Oscar Lewis before him, has been appropriated to make a similarly cultural framing for poverty, leading him to stress the importance of structural factors in framing social problems

Just because cultural explanations resonate with policy makers and the public today does not mean that structural explanations cannot resonate with them tomorrow. To shift political frames, however, and hopefully provide a more balanced discussion, requires parallel efforts among politicians, engaged citizens, and scholars. (2009, p. 139)

Wilson (2009) provides data comparing attitudes among Europeans and Americans that indicate that Americans overwhelmingly explain the existence of poverty as an individual shortcoming, whereas Europeans "focus much more on structural and social inequalities at large, not on individual behavior, to explain the causes of poverty and joblessness" (Wilson, 2009, p. 45-46). Lakoff (2008) has taken this notion of framing further, demonstrating that our brains use the logic of frames, prototypes, and metaphors to make sense of the world, not the logic of rational argument.

These findings have important implications for the "relevance" of qualitative scholarship. First, qualitative scholarship that focuses solely on the everyday micro-level reality of social interaction, may, like Lewis or Wilson, unwittingly contribute to a micro-level, cultural explanation for social phenomena that the U.S. citizenry are already prone to accept. Even progressive work on gendered, racial, or class-based micro-aggressions or deficit thinking may tend to fail to contextualize these in broader structures of patriarchy, racism, or economic exploitation (Dumas, 2011; Fraser, 2000; Leonardo, 2012). Second, if, as Lakoff (2008) suggests, support of policies is based on framing, prototypes, and metaphors more then rational argument, perhaps this means that qualitative scholars may have to rethink current representations and conduits of knowledge production.

Qualitative scholarship in education has too often led to a view that assumes that interventions at the individual and cultural level will solve problems that are largely structural. We see this with the recent popularity of "no excuses" or explicitly paternalistic schools that provide cultural "make-overs" for low-income urban children of color, but little in the way of structural analysis (Whitman, 2008). For immigrant children, such studies have often led to narrow assimilationist strategies that are what Cummins (1986) and later Valenzuela (1999) refer to as "subtractive."

\section{From Policy Prescription to Policy Knowledge}

To the extent that policymakers and educational leaders rely on educational scholarship, it is often less to formulate policy than to justify or provide support for specific policy proposals already under consideration. Sometimes, they may look to research in the policy development stage, in 
search of evidence of "what works," or perhaps to make a claim about what doesn't work. For example, most recently, conservative policymakers and media pundits have claimed that research "proves" that early childhood interventions such as Head Start are ineffective, since they do not lead to educational gains past the early elementary years. This dismisses the learning and developmental gains that are tied to participation in these early interventions, and also conveniently doesn't interpret these findings as suggesting the need for similar interventions in the mid-childhood years. Still, the larger problem here is using scholarship to prescribe policy, as if scholarship can provide a simple "thumbs up" or "thumbs down," and as if that is all, or even the most important thing we can learn from rigorous policy research.

We encourage scholars to resist the urge to frame their findings and analyses in ways that too easily get co-opted for the purpose of policy prescription. In its place, we advocate a shift toward offering our work as a contribution toward policy knowledge. Policy knowledge might be defined as information and ideas useful in framing, deepening our understanding of, and/or enriching our conceptualization of policy problems. Certainly, policy knowledge is found in the analysis of empirical data from one study or a set of related studies. It can also be offered in the explanation of decisions made in a specific research design or a broad discussion of challenges in the design of inquiry focused on a particular process or phenomenon. Perhaps most importantly, however, policy knowledge may take the form of deliberation on the nature of the policy problem itself (Bacchi, 1999).

McLaughlin (2006) notes that "what a policy concern is assumed to be a "problem of" (p. 210) heavily informs policy and research on that policy. Moreover, once policy advocates have determined what they believe explains the problem, other possible explanations are discarded, and largely left unconsidered, unresearched, and unaddressed in policy implementation. The "problem of the problem" (p. 210) is particularly challenging in education policy because there are so many human actors involved in the process of teaching and learning, including administrators, teachers, and students themselves. We may attempt to "deliver" and then assess schooling as one does a product in the marketplace; however, much of what happens in education is dependent on a range of human processes, and human responses to various interventions.

For example, McLaughlin asks, "Is disappointing student achievement a problem of inadequate standards? Shoddy curriculum? Poorly prepared teachers? An overly bureaucratic education system?” (p. 210). Or, thinking about the problem more contextually, student achievement might be affected by lack of access to material resources, persistent family and neighborhood poverty, and structural forms of racial and economic marginalization. And then, from another view, the problem of low student achievement has been determined to be a problem of values, in which students, families, neighborhoods, even whole racial/ethnic groups, are seen as not possessing the requisite inherent motivation or interest necessary to achieve.

Determining what policy is a "problem of" is certainly influenced by ideology, and we need not deny that in our sharing of policy knowledge. However, rather than evaluate which ideological position is most defensible, policy scholars might do better to explain the policy implications of different ideological positions. As McLaughlin explains, "Implementation researchers can identify the ideological base of a policy and elaborate the consequences of policies derived from it, document consequences, and assess trade-offs." However, McLaughlin insists, "Research cannot and should not evaluate underlying beliefs" (p. 211).

We would argue that while McLaughlin is correct to advocate that implementation scholars evaluate the policy implications of ideological positions rather than the positions themselves, our understanding of policy knowledge leaves space for rich discussion of philosophical and theoretical foundations as well, since this kind of knowledge can illuminate important tensions, contradictions 
and relations of power in education. However, it is useful to delineate, and be transparent about, how each functions as a source of policy knowledge.

The political right has been successful in using think tanks to provide policy knowledge and frame problems in ways that promote their ideological interests. Educational researchers have a much stronger knowledge base, but have struggled unsuccessfully to enter the policy conversation. Many of the most important policy battles take place not over policy prescription, but rather over whose knowledge becomes the new policy common sense.

\section{The Problem of Complexity}

An emphasis on policy knowledge encourages policymakers and other stakeholders to understand education as necessarily complex, but promises to provide them information and guidance they need to understand and act within that complexity. "Usable' [policy] knowledge," Honig (2006) states, "should seek to highlight and sort through the complexity that is fundamental to implementation in contemporary education policy arenas" (p. 22). Rather than oversimplify policy processes or merely prescribe interventions, we should aim to convince policymakers (and policy consumers) that understanding and engaging education as a complex set of interconnected interests, phenomena, and challenges is simply more honest, and promises to spark the kind of innovation that ultimately improves education and enters the policy ecology in more complex ways (WeaverHightower, 2008).

But academic researchers - even some qualitative researchers-and policy-makers too often see complexity, not as an asset, but rather as a problem. For instance, Donmoyer (2012) points out that given the tendency of academics to reduce complex phenomena to variables, think in terms of ideal types, and construct theory, complexity, of necessity, has to be reduced. He argues that, most academics have a vested interest in keeping complexity at bay, and, in this respect, at least, they are like members of the policy community. Given their shared preference for simplification, it should not be surprising that policymakers and many academics (especially those who embrace the use of quantitative research methods) are natural allies. (p. 803)

Biesta (2007) has also addressed the problem of reductionism, pointing out that, "evidence-based practice relies on a causal model of professional action. It is based on the idea that professionals do something - they administer a treatment, they intervene in a particular situation-in order to bring about certain effects (p. 7)." Biesta argues that such a view may be appropriate for some conceptions of medicine, but not for education. Education, he argues is not a physical interaction but rather a process of symbolic or symbolically mediated interaction. If teaching is to have any effect on learning, it is because of the fact that students interpret and try to make sense of what they are being taught. It is only through processes of (mutual) interpretation that education is possible." (p. 8)

And, of course, the same is true of the ways policy is implemented in schools. Policies and curricula that are the product of experimental designs have to be implemented with fidelity, when 30 years of implementation research argues that successful implementation is a process of mutual adaptation between the program and the implementers (McLaughlin, 1976; Spillane, Reiser, \& Reimer, 2002). Such a view of implementation requires a different kind of policy knowledge.

Some theorists suggest that we need to rethink the very nature of policy, not as a set of policy actors or advocacy for a particular issue, but rather as a complex ecology. For instance, Weaver-Hightower (2008) calls for thinking about a policy ecology and echoes our call for greater complexity in policy research. According to Weaver-Hightower, ... a policy ecology consists of the policy itself along with all of the texts, histories, 
people, places, groups, traditions, economic and political conditions, institutions, and relationships that affect it or that it affects. Every contextual factor and person contributing to or influenced by a policy in any capacity, both before and after its creation and implementation, is part of a complex ecology. (p. 155)

This approach suggests that it might be more helpful to view complexity as less a need for reductionism, than a need to foreground and background issues. So for instance, we may be studying school closings, but our scholarship can't ignore the possible relationship to the opening of new prisons. Unless we address this complexity in our work, research reductionism will result in policy reductionism.

Welner (2011) makes a similar case, but instead of using the notion of a policy ecology, he refers to zones that surround policy-makers. He claims that the objective is to enter this zone around a particular policy-maker and to do so early on. Lobbyists are well aware of this notion as they attempt to influence a particular legislator. Because qualitative researchers often contribute to amicus briefs, Welner asks why amicus briefs so seldom impact the decisions of judges. Echoing Weiss's (1977) notion of illumination, Welner argues that,

Each brief is simply one force that shapes the zone surrounding the decision, added to a myriad of existing and new forces, including a judge's own values and beliefs. For this reason, the research presented in such a brief, if it is to have an impact, is most effective if it is heard and considered long before the brief itself is filed. (p. 11) This notion of policy ecologies or zones, supports the idea that policy knowledge may be more important than policy prescription and that it must enter the policy conversation at the problem definition stage.

\section{Complexity and Social Context}

Attending to the complexity of educational policy offers a challenge to reductionist conceptualizations of causality in which structural and institutional dimensions of policy problems are usually overlooked or dismissed (Anderson \& Scott, 2012; Smith, 2005). Even if we account for choices made by individual students, teachers, or families, complexity demands that we situate these choices within broader social, historical, and economic contexts. It is not to say that low student achievement, for example, is caused by contextual factors in some direct way; rather, it is to say that we cannot know what we need to know about low student achievement without considering context as a dimension of policy knowledge.

As Anderson and Scott (2012) explain, we can follow the problem like "a trail of breadcrumbs" that "lead[s] from low achievement back to poverty, and ultimately, to structural inequality" (p. 679). Such complexity is not an excuse for educational inaction, a kind of passing the buck from school reform to social reform, as if nothing we do in the educational arena matters unless and until broader inequities are addressed. However, clear patterns of relationships between poverty or racial isolation (for example) and educational outcomes allows us to think more complexly about the impact of structural factors on the reproduction of social and educational inequities across time and space. In other words, if we can almost predict educational outcomes or life chances based on zip code or family income, then this indeed is policy knowledge that must be considered in determination of "the problem of the problem," and then, in any genuine policy effort to address persistent educational inequality.

Now, this is all easier said than done, for several reasons. We acknowledge that a shift from policy prescription to policy knowledge is an inherently ideological project, even if it can be defended on the basis of scholarly integrity or methodological rigor alone. That is, one need not be a critical or radical scholar to understand that the very idea of scholarship is undermined by narrow 
conceptualizations of causation, or delimiting what counts as educational policy despite evidence that expands the field of inquiry. However, policy knowledge-even the discursive act of situating those two words next to one another-is inherently political, since it invites an interrogation of all the ideological and material forces that keep policy and knowledge apart.

For instance, Lather (2006) reminds us that policy functions "to regulate behavior and render populations productive via a 'biopolitics' that entails state intervention in and regulation of the everyday lives of citizens in a 'liberal' enough manner to minimize resistance and maximize wealth stabilization" (p. 787). Educational policy research offers just enough empathy with the dispossessed, and demonstrates just enough impatience with inaction to secure for itself an innocent, even heroic place in public discourse. However, to the extent that scholarship threatens to unsettle relations of power by grappling with complex theoretical ideas about justice or democracy, or presenting thick description that follows children, families or educational processes wherever they may go_- to the extent that scholarship insists on complexity-it opens itself up to charges of irrelevance, of unnecessary obfuscation, of wasting time and resources in a time of educational crisis.

What counts as evidence, what is allowed to count as policy knowledge, is, as Lather suggests, heavily regulated. "Where there are problems," Humes and Bryce contend, "policy-makers switch to the defensive, whereas researchers see problems as opportunities for further reflection and investigation. Few policy makers (if any) seek to encourage research evidence relevant to problems that must be tackled in the course of implementation. Threatened positions foreclose on further scrutiny; facts, worse still new facts, just get in the way of managerial imperatives and political credibility" (p. 348). Policy knowledge highlights what we do not yet know, and sees that as a form of knowledge in itself, since for scholars identifying contradictions and uncertainties is moving a step closer toward illumination of the problem itself. To be sure, scholars must be sensitive to the pressures that policymakers face from corporate and state influences, and from the public. However, we have to be clear about our own ethical priorities and our professional commitment to knowledge production, despite, and perhaps especially in the face of resistance to more, and deeper knowledge.

Ultimately, to insist on policy knowledge is to "take the side of the messy" (Lather, 2006, p. 789), to "counter faith in a naïve and transparent social world" with a view of schools and communities situated within systematic processes of cultural misrecognition and economic maldistribution. Even if one does not adopt this critical view of relations of power, at very least, "the messy" of education policy involves a complex set of relations between people, places and policies (Honig, 2006) that must be understood, not so much to detangle — as if to simplify or explain away - but to gain a deeper understanding of the nature of their entanglement.

Stakes are high. "To fantasize such complexities away," Lather cautions, "is to yield impoverishment rather than improvement. That loss is being borne by the children, teachers and administrators in our schools under present accountability regimes and the neo-positivism that they spawn" (p. 789). Actual people are hurt by mere policy prescription. Our aim as scholars is not to protect some ideological or methodological turf. These are not, in the end, mere paradigm wars, but our ability to make meaning of, and craft creative, effective responses to human suffering, desires and aspirations.

\section{Toward a Scholarship of Public Engagement}

Not only do we need a shift from policy prescription to policy knowledge, we need to better understand how to more effectively engage traditional and new policy actors, as well as new audiences and new conduits that exist to those publics, such as open access venues, blogs, and social 
media (Willinsky, 2009). We are living through a historical shift away from Keynesian, welfare state policies toward neoclassical or neoliberal free-market policies (Harvey, 2005) that have resulted in growing social inequality (Wilkinson \& Pickett, 2010). These new policies also create changes across institutional fields that are manifested at the organizational level and in classrooms as the everyday experience of teaching and learning undergoes dramatic changes. These changes include the ways teachers are trained, the ways they are evaluated, the curriculum they teach, and the levels of professional autonomy they enjoy in schools and classrooms (Darling-Hammond, 2010). Nor can issues of race, class, and gender on the ground be divorced from these structural changes.

There are new players in the policy arena, including those that are driving current policy and those attempting to resist it. We may not have as much influence as we would like with the new drivers of policy (e.g., conservative think tanks, ideologically driven venture philanthropists and hedge fund managers, business associations, and edubusinesses and their lobbyists), but new networks of policy resisters are seeking alliances and forms of knowledge that we can provide, preferably in collaboration with these groups (e.g., community organizers, advocacy organizations, teachers unions, bloggers, journalists, parent groups).

These new grassroots advocacy organizations often seek support from academics and are often interested in more complex and critical forms of knowledge than traditional policy-makers ${ }^{3}$. As academic researchers begin collaborating with these grassroots groups, they are forced to rethink appropriate research methodologies and how they position themselves and are positioned by the groups they collaborate with.

If our aim is to convince policymakers, education advocates and grassroots organizers of the relevance of policy knowledge, we will need to more actively engage with a broader public outside of the academy. While we should not allow our research agendas to be dictated by government agencies or policymakers, we do need to be in conversation with them, and carefully consider their priorities, as they understand them. In short, we should be attentive to what it is they seek to know, even as our scholarship may indeed seek to expand that field of inquiry. That is, our work should be responsive to policy deliberation and policy priorities, but should also offer critique (even when none has been solicited) and a vision of policy as it could be. Thus, we become public intellectuals willing to participate in a broader discussion about the aims of education in a society with democratic aspirations. In this regard, our contribution as policy scholars is to ask critical questions and provide knowledge that can be used in policy development and implementation, and in evaluating the extent to which existing and new policies fulfill these collective aspirations. "In this sense," Humes and Bryce (2001) note, "scholarship has to move out of the study into the public arena where evidence, knowledge and values constitute contested terrain. The scholar-researcher has to be prepared to get his or her hands dirty" (p. 330).

Scholars will need to develop meaningful relationships with a range of audiences, depending on the topic, the stakeholders, the unit(s) of analysis, and chosen qualitative methodology (e.g., ethnography, case study, participatory action research). The relevance thus emerges from relationships. As Sallee and Flood (2012) explain, relevance "is thoroughly intertwined with relationships that are built and channels of communication that are opened. Researchers can enhance the relevance of their research by inviting community input and identifying practical solutions to problems" (2012, p. 141). In the next section, we provide several examples of attempts to broaden our audiences and enrich our relationships with these audiences, highlighting the methodological shifts necessary to co-construct policy knowledge that might aid in grassroots resistance work.

${ }^{3}$ Although they may often also need statistical, quantitative data. 


\section{New Audiences, New Relationships, and New Methods}

Many policy researchers are beginning to experiment with new approaches to providing research that is relevant to policy-makers, practitioners, or policy activists. For instance, Torrance (2008) and Somekh \& Schwandt (2007) suggest that many spend too much time arguing about quality standards for qualitative research from the perspective of the academy. They call for more direct engagement with policymakers around the production of knowledge. Torrance (2008) describes cases in Britain in which researchers design "studies with collaborating sponsors and participants, including policy makers, and talking through issues of validity, warrant, appropriate focus and trustworthiness of the results" (p. 522).

While Torrence acknowledges potential problems with cooptation and collusion, he argues that "if research is to engage with policy, then research and policy making must progress both theoretically and chronologically in tandem. Neither can claim precedence in the relationship" (p. 522). He argues that putting more emphasis on interacting with policymakers and less emphasis on NRC-style quality standards with their deficit view of qualitative or "humanities" research, might lead to the evolution of qualitative methods more useful to policymaking.

Another somewhat similar approach is what Smith-Merry (2012) call policy consultation, in which policy-makers develop policies in consultation with policy researchers. This approach is more common in Europe, but could perhaps be feasible in the U.S. at state and local levels. Typically when policy consultation occurs, it is with the corporate sector. Few Americans realize that corporate CEOs regularly sit down with policy-makers to write model bills that they send through state legislatures. But this is exactly what the American Legislative Exchange Council (ALEC) does (Anderson \& Montoro Donchik, 2013). These policy consultations between corporations and lawmakers helped produce the anti-labor laws in Wisconsin, the Stand Your Ground laws in Florida, and the Voter ID laws that were passed in over half of the states in the U.S.

Smith-Merry (2012) describes a different policy consultation process in which policy-makers and practitioners in public health, education, social work, and other professions engage in mutual education to impact both more effective implementation of policy, but also an opportunity for practitioners to "talk back" to policy-makers. Part of a move to more deliberative and participatory forms of policy-making, "consultation processes are forums specifically formulated in order to allow new policy ideas to be argued, tested, upheld or dismissed. They usually consist in the initial production of a policy document by the government, against which responses are collected." (SmithMerry, 2012, p. 133) The qualitative data that result from these forums or other forms of written feedback are a significant source of qualitative policy data that is collected at the point of contact between the policy and the practitioner.

How else might qualitative research provide accounts that are relevant in the context of current neoliberal policies? Many researchers have suggested the notion of testimonios or counternarratives that provide a unique standpoint that challenges dominant narratives of the poor or other non-dominant groups (Casey, 1995-1996). Clearly, one use of narrative and qualitative research could be to provide systematic accounts of the lived experience of neoliberal and managerialist policies that have created what scholars call an audit culture of high stakes assessment in schools and universities (Apple, 2005; Strathern, 2000).

Accounts are beginning to proliferate of the lived experiences of teachers (Gewirtz, 2002), principals (Cohen, 2013), and students (Cammarota \& Fine, 2008) under neoliberal regimes of intense performance management. Ball and Olmedo (2013) state, "we want to address the particular plight of the teacher who stands alone in their classroom or their staff common room, and sees something 'cracked', something that to their colleagues is no more than the steady drone of the mundane and the normal, and finds it intolerable" (p. 85). Qualitative researchers in collaboration 
with practitioner researchers could provide a significant body of work that documents the lived realities of policies on the ground.

For example, we (the authors) are involved in a collaborative research project aimed at understanding and reversing the decline of Black and Latino teachers in New York City schools. Led by Teachers Unite, an independent organization of teachers committed to racial and economic justice, the project brings together teacher-activists with faculty and graduate students to investigate the many dimensions of this crisis, from the racial and economic subjugation which make it less likely that Black and Latino students will graduate and pursue higher education, to the complex interplay of cultural and structural factors that make teaching unattractive and unattainable as a career choice, even for those who do make it to college.

Our work together includes critical analyses of extant scholarship, and pooling our resources to secure access to New York City Department of Education data related to the recruitment and retention of Black and Latino teachers. Here, for example, we have already discovered that while the Department of Education may be able to claim that the overall percentage of Black and Latino teachers - unimpressive as it is - has not declined significantly in recent years, the percentage of newly recruited Black and Latino teachers most certainly has. This indicates that Black and Latino teachers are generally older, and less likely to leave the field. As the Department of Education continues to hire more and more white teachers in a district that is overwhelmingly made up of children of color, and as these Black and Latino teachers begin to retire, we can expect to see fewer teachers of color overall, even as the pipeline to higher education in general and to careers in teaching more specifically becomes less accessible to new generations of students of color.

The foundation of our collaborative inquiry rests on an understanding that this trend is not by accident, but is the inevitable, and perhaps not entirely unintentional, result of neoliberal and managerialist logics and practices, which then inform and are informed by new rightist racial projects, leading to what might best be described as racial neoliberalism (Goldberg, 2009) or neoliberal multiculturalism (Melamed, 2009). The staff of Teachers Unite do not need universitybased researchers to tell them that this injustice is afoot. However, we believe scholarship may provide them access to useful theoretical concepts that help contextualize and complicate what they are seeing on the ground, and empirical data that critique policies that lead to racial disproportionality in teacher hiring and evaluation, document the experiences of current and aspiring teachers of color, and assess promising interventions to reverse the decline. Ultimately, this partnership between scholars and practitioners is intended to create amongst ourselves the policy knowledge we need to develop and push for new policies and practices that improve opportunities in teaching for people of color. For scholars, the project also offers us the ability to engage in inquiry that educators and communities are waiting for, inspired by the questions they are asking and the experiences they are having everyday in schools and neighborhoods.

Another example of how academic researchers have connected with grassroots movements is a participatory action research (PAR) project conducted by Fine, Torre, Boudin, Bowen, Clark, Hylton, Martinez, Roberts, Smart \& Upegui (2001) with inmates from a women's correctional facility, investigating the effects of college-in-prison programs on inmates' experiences while in prison, and its effect on recidivism and life chances after re-entry into the community. The research responds to the publicly acknowledged problem of higher rates of incarceration, particularly among African American women, and growing public opposition to funding higher education and training opportunities for women while they are incarcerated.

The university-based researchers joined with inmate researchers to design the project, which included both quantitative and qualitative inquiry over the course of three years. Specific qualitative methods included focus groups and individual interviews, and archival analysis of women's 
experiences in the prison going back to the 1970s. Findings indicated that college-in-prison programs for women reduce recidivism and facilitate an easier transition back into society. Also, the existence of a college-in-prison program had a positive effect on the prison experience, not only for the inmates, but also for the personnel responsible for managing the prison.

Not content to simply report their findings in a journal, Fine and her colleagues, including the inmate researchers, developed a knowledge dissemination strategy that included a website (http://web.gc.cuny.edu/che/changingminds.html), a range of endorsements from influential elected officials, community-based advocates, and even individuals whose relatives had been victims of violent crimes. Attractive brochures and postcards featuring key findings, policy ideas, and biographies and photos of former inmates were mailed to policymakers and government officials in all 50 states.

Finally, we want to urge AERA and other education research organizations to join with other professional academic groups, including the American Anthropological Association (AAA), the American Psychological Association (APA) and the American Sociological Association (ASA), in finding a way to more effectively communicate policy knowledge related to key political issues in which we have a vested scholarly interest, and a compelling contribution to make. Here, we might act not so much as ideological advocates of specific policy proposals; this we might best leave to individual scholar-activists, working in collaboration with community-based organizations. Rather, our professional associations might act as education knowledge advocates, issuing papers and submitting court briefs, which summarize and explain the findings of specific areas of education research for various lay and public policy audiences. In providing reviews of the extant literature, we become advocates for policy deliberation and decision-making that is informed by the preponderance of evidence in the field. Most recently, for example, all three of the aforementioned professional associations-ASA, APA and AAA - were among a broad range of academic organizations which submitted amicus briefs to the US Supreme Court in support of the overturn of the discriminatory Defense of Marriage Act (DOMA). In each document, scholars explained the significance of the approach to inquiry in the discipline, offered an understanding of concepts and units of analysis commonly used in each field (e.g., family, culture, child development, emotional well-being), and then summarized the findings of research relevant to the issues in the case. Arguably, given work in our field on homophobia in schools and on LGBT youth and families, education scholars could have also weighed in with policy knowledge on this case. However, AERA neglected to do so, although it did file an amicus brief on the Fischer vs. The University of Texas at Austin affirmative action case. Our professional organizations have also been woefully silent about issues more directly related to school organization and pedagogy, including school closings, teacher evaluations, charter schools, and state takeovers and mayoral control of districts.

\section{Conclusion}

This brings us back to our original concerns about the ability of qualitative researchbroadly defined - to be relevant to policy makers, practitioners, and other stakeholders. In the aftermath of the NRC report and the debates that followed, there is a tendency to acknowledge that research that is not quantitative may be legitimate research, but it simply is not scientific research. The new language for this seems to be a "social science" vs. "humanities" binary. As policy prescription related to "what works" becomes more hegemonic, qualitative research is defined as nonscientific, meaning in part, lacking the methodological tools that allow for social prediction. As we have attempted to demonstrate, if we shift the notion of policy prescription to policy knowledge and broaden our notion of who our audiences are and how we might engage them, then qualitative 
research has a more robust role to play.

Perhaps we can take a page from Milton Freidman's playbook. After all, he was arguably far more successful at changing how policies were framed than any other recent public scholar. In explaining what he considered the crumbling of the Welfare State in the U.S. and the disillusionment of liberal and left intellectuals with the Vietnam War, Freidman argues in his 1982 preface to

\section{Capitalism and Freedom,}

These phenomena, not the persuasiveness of the ideas expressed in books dealing with principles, explain the transition from the overwhelming defeat of Barry

Goldwater in 1964 to the overwhelming victory of Ronald Reagan in 1980 - two men with essentially the same program and the same message.

What then is the role of books like this? Twofold in my opinion. First to provide subject matter for bull sessions. As we wrote in the preface to Free to Choose: 'The only person who can truly persuade you is yourself. You must turn the issues over in your mind at leisure, consider the many arguments, let them simmer, and after a long time turn your preferences into convictions.'

Second, and more basic, to keep options open until circumstances make change necessary. There is enormous inertia — a tyranny of the status quo-in private and especially government arrangements. Only a crisis—actual or perceived-produces real change. When that crisis occurs, the actions that are taken depend on the ideas that are lying around. That, I believe, is our basic function: To develop alternatives to existing policies, to keep them alive and available until the politically impossible becomes politically inevitable (p. ix).

Much like Weiss's notion of the percolation of ideas and the illumination function of academic scholarship, Freidman and his followers laid the groundwork for the ideas that were taken up to dramatically change our common sense notions about how the world works and the role of education in society. Only by better understanding why educational policy has been so effectively influenced by ideologues of the political right, can we begin to create policy knowledge that might be effective in producing an alternative common sense. However, the ideas we want lying around cannot merely be based on ideology, they must be founded on rigorous policy knowledge that honors complexity.

\section{References}

Amrein-Beardsley, A. (2008). Methodological concerns about the education value-added assessment system. Educational Researcher, 37(2008), 65-75. http://dx.doi.org/10.3102/0013189X08316420

Anderson, G.L., \& Herr, K. (1999). The new paradigm wars. Is there room for rigorous practitioner knowledge in schools and universities? Educational Researcher, 28(5), 12-21. http://dx.doi.org/10.3102/0013189X028005012

Anderson, G.L., \& Scott, J. (2012). Toward an intersectional understanding of social context and causality. Qualitative Inquiry, 18(8). http://dx.doi.org/10.1177/1077800412452857

Anderson, G.L., \& Montoro Donchik, L. (2013). The privatization of education and policy-making: The American Legislative Exchange Council (ALEC) and new modalities of governance. Paper presented at 
the Annual Meeting of the American Educational Research Association, April, 28, San Francisco.

Anyon, J. (2005). Radical possibilities: Public policy, urban education and a new social movement. New York: Routledge.

Apple, M. (2005). Education, markets, and an audit culture. Critical Quarterly, 47, 11-29. http://dx.doi.org/10.1111/j.0011-1562.2005.00611.x

Bacchi, C. L. (1999). Women, policy and politics. The construction of policy problems. London: Sage.

Ball, S. (2010). New Voices, New Knowledges and the New Politics of Education Research: the gathering of a perfect storm? European Educational Research Journal, 9(2), 124-137. http://dx.doi.org/10.2304/eerj.2010.9.2.124

Ball, S., \& Olmedo, A. (2013): Care of the self, resistance and subjectivity under neoliberal governmentalities. Critical Studies in Education, 54(1), 85-96. http://dx.doi.org/10.1080/17508487.2013.740678

Berman, P. \& McLaughlin, M. (1978). Federal programs supporting educational change. Monica, CA: Rand Corporation.

Biesta, G. (2007). Why “what works" won't work: Evidence-based practice and the democratic deficit in educational research. Educational Theory, 57(1), 1-22. http://dx.doi.org/10.1111/j.1741-5446.2006.00241.x

Braun, A., Ball, S., Maguire, M., Hoskins, K. (2011). Taking context seriously: Towards explaining policy enactments in the secondary school. Discourse: Studies in the cultural politics of education, 32:4, 585-596. http://dx.doi.org/10.1080/01596306.2011.601555

Carnoy, M., Loeb, S., \& Smith, T.L. (2000). Do higher state test scores in Texas make for better high school outcomes? Paper presented at the annual meeting of the American Educational Research Association, New Orleans.

Center for Research on Education Outcomes. (2009). Multiple choice: Charter school performance in 16 states. Stanford, CA: Stanford University.

Cammarota, J. \& Fine, M. (Eds.) (2008). Revolutionalizing education: Youth participatory action research in motion. New York, NY: Routledge.

Casey, K. (1995-1996). The new narrative research in education. Review of Educational Research, 21, 211-25.

Clandinin, J., \& Connelly, M. (1995). Teachers' professional knowledge landscapes. New York: Teachers College Press.

Cohen, M. (2013). In the back of our minds always': reflexivity as resistance for the performing principal. International Journal of Leadership in Education, 1-22.

Cummins, J. (1986). Empowering minority students: A framework for intervention. Harvard Educational Review, 56(4), 649-657.

Darling Hammond, L., Amrien-Beardsley, A., Haertel, E. H., \& Rothstein, J. (2011). Getting teacher evaluation right: A background paper for policy makers, Capitol Hill research briefing. Washington, DC: American Educational Research Association and the National Academy of Education.

Dillon, S. (2011, April 27). Foundations join to offer online courses for schools. New York Times. Retrieved from http://www.nytimes.com/2011/04/28/education/28gates.html

Donmoyer, R. (2012). Can Qualitative Researchers Answer Policymakers' What-Works Questions? Qualitative Inquiry, 18(8), 662-673. http://dx.doi.org/10.1177/1077800412454531

Dumas, M. (2011). A cultural political economy of school desegragation in Seattle. Teachers College Record, 113(4), 704-34.

Ercikan, K., \& Roth, W.M. (2006). What good Is polarizing research into qualitative and quantitative? Educational Researcher, 35(5), 14-23. 
http://dx.doi.org/10.3102/0013189X035005014

Erickson, F., \& Gutierrez, K. (2002). Culture, rigor, and science in educational research. Educational Researcher, 31(8), 21-24. http://dx.doi.org/10.3102/0013189X031008021

Fine, M., Torre, M.E., Boudin, K., Bowen, I., Clark, J., Hylton, D., Migdalia Martinez, M., Roberts, R.A., Smart, P., \& Upegui, D. (2001). Changing minds: The impact of college in a maximum security prison [Monograph]. Retrieved from http://web.gc.cuny.edu/che/changingminds.html

Fraser, N. (2000). Rethinking recognition. New Left Review, 3, 107-120.

Friedman, M. (1962). Capitalism and Freedom. Chicago: University of Chicago Press.

Gage, N.L. (1989). The paradigm wars and their aftermath: A "historical" sketch of research on teaching since 1989. Educational Researcher, 18(7), 4-10.

Gewirtz, S. (2002). The managerial school: Post-welfarism and social justice in education. London: Routledge.

Ginsberg, M. \& Gorostiaga, J. (2001). Relationships between theorists/researchers and policy makers/practitioners: Rethinking the two cultures thesis and the possibility of dialogue. Comparative Education Review, 45(2), 173- 189. http:/ /dx.doi.org/10.1086/447660

Glaser, B., \& Strauss, A. (1967). The discovery of grounded theory: Strategies for qualitative research. Chicago, Aldine Pub.

Goldberg, D.T. (2009). The threat of race: Reflections on racial neoliberalism. Malden, MA: Blackwell.

Haney, W. (2000). The myth of the Texas miracle in education. Educational Policy Analysis Archives, 8(41) [On-line]. Available at http://epaa.asu.edu/ojs/article/view/432

Hardy, I. (2009). The politics of educational policy studies: a preliminary analysis of leading educational policy journal publications, Critical Studies in Education, 50(2),173-185. http://dx.doi.org/10.1080/17508480902859441

Harvey, D. (2005). A brief history of neoliberalism. London, UK: Oxford University Press.

Honig. M.I. (2006). Complexity and policy implementation: Challenges and opportunities for the field. In M.I. Honig (Ed.), New directions in educational policy implementation: Confronting complexity (pp. 1-23). Albany, NY: SUNY.

Hoxby, C. (2004). A Straightforward Comparison of Charter Schools and Regular Public Schools in the United States. Mimeo. Cambridge, MA: Harvard University. Available at http://post.economics.harvard.edu/faculty/hoxby/papers/charters_040909.pdf.

Humes, W., \& Bryce, T. (2001). Scholarship, research and the evidential basis of policy development in education. British Journal of Educational Studies, 49(3), 329-352. http://dx.doi.org/10.1111/1467-8527.t01-1-00179

Klein, S.P., Hamilton, L.S., McCaffrey, D.F., \& Stecher, B.M. (2000). What do test scores in Texas tell us? (RAND Education Issue Paper) Available: www.rand.org/publications/IP/IP202.

Labaree, D. (2011). The lure of statistics for educational researchers. Educational Theory, 61(6), 621632. http://dx.doi.org/10.1111/j.1741-5446.2011.00424.x

Lakoff, G. (2008). The Political Mind. New York: Viking.

Lather, P. (2004). This IS your father's paradigm: Government intrusion and the case of qualitative research in education. Qualitative Inquiry, 10(1), 15-34. http://dx.doi.org/10.1177/1077800403256154

Lather, P. (2006). Foucauldian scientificity: rethinking the nexus of qualitative research and educational policy analysis. International Journal of Qualitative Studies in Education, 19(6), pp. 783791. http://dx.doi.org/10.1080/09518390600976006

Leonardo, Z. (2012). The race for class: Reflections on a critical raceclass theory of education. Educational Studies, 48(5), 427-449. http://dx.doi.org/10.1080/00131946.2012.715831

Lincoln, Y., \& Guba, E. (1985). Naturalistic Inquiry. Thousand Oakes, CA: Sage. 
Lipman, P. (2011). The new political economy of urban education: Neoliberalism, race, and the right to the city. New York: Routledge.

Melamed, J. (2009). Represent and destroy: Rationalizing violence in the new racial capitalism. Minneapolis: University of Minnesota.

National Research Council (2002). Scientific research in education (R.J. Shavelson and L. Towne, Eds.; Committee on Scientific Principles for Education Research) Washington, D.C. National Academic Press.

Noblitt, G., \& Hare, R. D. (1988). Meta-ethnography: Synthesiz̨ing qualitative studies. Thousand Oaks, CA: SAGE.

McLaughlin, M. (1976). Implementation as mutual adaptation: Change in classroom organization. Teachers College Record, 77(3), 339-351.

Ozga, J. (2008) Governing Knowledge: research steering and research quality. European Educational Research Journal, 7(3), 261-272. http://dx.doi.org/10.2304/eerj.2008.7.3.261

Payne, C. (2008). So much reform, so little change: The persistence of failure in urban schools. Cambridge, MA: Harvard Education Press.

Sallee, M.W., \& Flood, J.T. (2012). Using qualitative research to bridge research, policy and practice. Theory into Practice, 51(2), 137-144. http://dx.doi.org/10.1080/00405841.2012.662873

Scott, J. (2009). The politics of venture philanthropy in charter school policy and advocacy. Educational Policy, 23(1), 106-136. http://dx.doi.org/10.1177/0895904808328531

Scott, J. (2011). Market-driven education reform and the racial politics of advocacy. Peabody Journal of Education, 86, 580-599. http://dx.doi.org/10.1080/0161956X.2011.616445

Scott, J., \& Fruchter, N. (2009). Community resistance to school privatization: The case of New York City. In R. Fisher (Ed.), The people shall rule: ACORN, community organizing, and the struggle for economic justice (pp. 180-205). Nashville, TN: Vanderbilt University Press.

Shaker, P., \& Heilman, E. (2004). The new common sense of education: Advocacy research versus academic authority. Teachers College Record, 106(7), 1444-1470. http://dx.doi.org/10.1111/j.1467-9620.2004.00385.x

Smith, D. (2005). Institutional ethnography: A sociology for people. Lanham, MD: Alta Mira Press.

Smith-Merry, J. (2012). Experiential knowledge in action: Consulting practitioners for policy change. Policy and Society 31, 131-143. http://dx.doi.org/10.1016/j.polsoc.2012.04.002

Somekh, B., \& Schwandt, T. (Eds.). (2007). Knowledge production: The work of educational research in interesting times. London: Routledge.

Spillane, J., Reiser, B., \& Reimer, T. (2002). Policy Implementation and Cognition: Reframing and Refocusing Implementation Research, Review of Educational Research, 72(3), 387-431. http://dx.doi.org/10.3102/00346543072003387

St. Clair, R. \& Belzer, A. (2007). In the Market for ideas: How reforms in the political economy of educational research in the US and UK promote market managerialism. Comparative Education, 43(4), 471-488. http://dx.doi.org/10.1080/03050060701611870

Stone, D. (2001). Policy paradox ( $3^{\text {rd }}$ edition). New York: W.W. Norton.

Strathern, M. (Ed.) (2000). Audit cultures: Anthropological studies in accountability, ethics, and the academy. London: Routledge. http://dx.doi.org/10.4324/9780203449721

Torrance, H. (2008). Building confidence in qualitative research: Engaging the demands of policy. Qualitative Inquiry, 14(4), 507-527. http://dx.doi.org/10.1177/1077800407309380

Valenzuela, A. (1999). Subtractive schooling: U.S. Mexican youth and the politics of caring. Albany, NY: SUNY Press.

Vasquez Heilig, J., \& Darling-Hammond, L. (2008). Accountability Texas-style: The progress and learning of urban minority students in a high-stakes testing context. Educational Evaluation and 
Policy Analysis, 30(2), 75-110. http://dx.doi.org/10.3102/0162373708317689

Verschuren, P. (2001). Holism versus reductionism in modern social science research. Quality \& Quantity, 35, 389-405. http://dx.doi.org/10.1023/A:1012242620544

Ward, S. (2011). The machinations of managerialsim: New public management and the diminishing power of professionals. Journal of Cultural Economy, 4(2), 205-215. http://dx.doi.org/10.1080/17530350.2011.563072

Warren, M., \& Mapp, K. (Eds.) (2011). A match on dry grass: Community organizing as a catalyst for school reform. New York: Oxford University Press.

Wayman, J., \& Springfield, S. (2006). Technology-supported involvement of entire faculties in examination of student data for instructional improvement. American Journal of Education, 112(4), 549-571. http://dx.doi.org/10.1086/505059

Weaver-Hightower, M. (2008). An ecology metaphor for educational policy analysis: A call to complexity. Educational Researcher, 37(3), 153-167. http://dx.doi.org/10.3102/0013189X08318050

Weatherley, R. ,\& Lipsky, M. (1977). Street Level Bureaucrats and Institutional Innovation: Implementing Special Education Reform. Harvard Educational Review 47, 171-97.

Weiss, C. (1977). Research for policy's sake: The enlightenment function of social research. Policy Analysis, 3(Fall), 531-545.

Welner, K. (2010). Scholars as policy actors: Research, public discourse, and the Zone of judicial constraints. American Educational Research Journal, 49(1), 7-29. http://dx.doi.org/10.3102/0002831211415253

Whitman, D. (2008). Sweating the small stuff: Inner-city schools and the new paternalism. Washington, D.C.: Thomas B. Fordham Institute

Wilkinson, R., \& Pickett, K. (2010). The Spirit level: Why greater equality makes societies stronger. New York: Bloomsbury Press.

Willinsky, J. (2009). The open access principle. Cambridge, MA: MIT Press.

Wilson, W. J. (2009). More than just race: Being Black and poor in the inner city. New York: W.W. Norton.

Wiseman, A. (2010). The uses of evidence for educational policymaking: Global contexts and international trends. Review of Research in Education 34, 1-24. http://dx.doi.org/10.3102/0091732X09350472 


\section{About the Authors}

Michael J. Dumas

Assistant Professor of Educational Leadership

New York University

michael.dumas@,nyu.edu

Michael J. Dumas is assistant professor of educational leadership at the Steinhardt School of Culture, Education and Human Development, New York University. His research interests are related to the cultural political economy of urban education and the cultural politics of Black education.

Gary Anderson

Professor of Educational Administration

New York University

gary.anderson@,nyu.edu

Gary Anderson is a professor of educational leadership at the Steinhardt School of Culture, education and Human Development, New York University. A former high school teacher and principal, he has published on topics such as critical ethnography, action research, school micropolitics, and school reform and leadership.

\section{SPECIAL ISSUE} Qualitative Inquiry

\section{education policy analysis archives}

Volume 21 Number 11
February 17th, 2014
ISSN 1068-2341

\section{(c)}

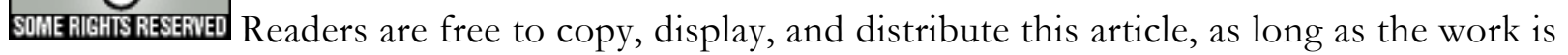
attributed to the author(s) and Education Policy Analysis Archives, it is distributed for noncommercial purposes only, and no alteration or transformation is made in the work. More details of this Creative Commons license are available at http://creativecommons.org/licenses/by-nc-sa/3.0/. All other uses must be approved by the author(s) or EPAA. EPAA is published by the Mary Lou Fulton Institute and Graduate School of Education at Arizona State University Articles are indexed in CIRC (Clasificación Integrada de Revistas Científicas, Spain), DIALNET (Spain), Directory of Open Access Journals, EBSCO Education Research Complete, ERIC, Education Full Text (H.W. Wilson), QUALIS A2 (Brazil), SCImago Journal Rank; SCOPUS, SOCOLAR (China).Please contribute commentaries at http://epaa.info/wordpress/ and send errata notes to Gustavo E. Fischman fischman@asu.edu

Join EPAA's Facebook community at https://www.facebook.com/EPAAAAPE, Twitter feed @epaa_aape, and Academia.edu page at: http://asu.academia.edu/EPAAAAPE 


\section{education policy analysis archives editorial board}

Editor Gustavo E. Fischman (Arizona State University)

Associate Editors: David R. Garcia (Arizona State University), Stephen Lawton (Arizona State University)

Rick Mintrop, (University of California, Berkeley) Jeanne M. Powers (Arizona State University)

Jessica Allen University of Colorado, Boulder

Gary Anderson New York University

Michael W. Apple University of Wisconsin, Madison

Angela Arzubiaga Arizona State University

David C. Berliner Arizona State University

Robert Bickel Marshall University

Henry Braun Boston College

Eric Camburn University of Wisconsin, Madison

Wendy C. Chi* University of Colorado, Boulder

Casey Cobb University of Connecticut

Arnold Danzig Arizona State University

Antonia Darder University of Illinois, UrbanaChampaign

Linda Darling-Hammond Stanford University

Chad d'Entremont Strategies for Children

John Diamond Harvard University

Tara Donahue Learning Point Associates

Sherman Dorn University of South Florida

Christopher Joseph Frey Bowling Green State University

Melissa Lynn Freeman* Adams State College

Amy Garrett Dikkers University of Minnesota

Gene V Glass Arizona State University

Ronald Glass University of California, Santa Cruz

Harvey Goldstein Bristol University

Jacob P. K. Gross Indiana University

Eric M. Haas WestEd

Kimberly Joy Howard* University of Southern California

Aimee Howley Ohio University

Craig Howley Ohio University

Steve Klees University of Maryland

Jaekyung Lee SUNY Buffalo
Christopher Lubienski University of Illinois, UrbanaChampaign

Sarah Lubienski University of Illinois, UrbanaChampaign

Samuel R. Lucas University of California, Berkeley

Maria Martinez-Coslo University of Texas, Arlington

William Mathis University of Colorado, Boulder

Tristan McCowan Institute of Education, London

Heinrich Mintrop University of California, Berkeley

Michele S. Moses University of Colorado, Boulder

Julianne Moss University of Melbourne

Sharon Nichols University of Texas, San Antonio

Noga O'Connor University of Iowa

João Paraskveva University of Massachusetts, Dartmouth

Laurence Parker University of Illinois, UrbanaChampaign

Susan L. Robertson Bristol University

John Rogers University of California, Los Angeles

A. G. Rud Purdue University

Felicia C. Sanders The Pennsylvania State University

Janelle Scott University of California, Berkeley

Kimberly Scott Arizona State University

Dorothy Shipps Baruch College/CUNY

Maria Teresa Tatto Michigan State University

Larisa Warhol University of Connecticut

Cally Waite Social Science Research Council

John Weathers University of Colorado, Colorado Springs

Kevin Welner University of Colorado, Boulder

Ed Wiley University of Colorado, Boulder

Terrence G. Wiley Arizona State University

John Willinsky Stanford University

Kyo Yamashiro University of California, Los Angeles

* Members of the New Scholars Board 


\section{archivos analíticos de políticas educativas consejo editorial}

Editor: Gustavo E. Fischman (Arizona State University)

Editores. Asociados Alejandro Canales (UNAM) y Jesús Romero Morante (Universidad de Cantabria)

Armando Alcántara Santuario Instituto de Investigaciones sobre la Universidad y la Educación, UNAM México

Claudio Almonacid Universidad Metropolitana de Ciencias de la Educación, Chile

Pilar Arnaiz Sánchez Universidad de Murcia, España

Xavier Besalú Costa Universitat de Girona, España Jose Joaquin Brunner Universidad Diego Portales, Chile

Damián Canales Sánchez Instituto Nacional para la Evaluación de la Educación, México

María Caridad García Universidad Católica del Norte, Chile

Raimundo Cuesta Fernández IES Fray Luis de León, España

Marco Antonio Delgado Fuentes Universidad Iberoamericana, México

Inés Dussel FLACSO, Argentina

Rafael Feito Alonso Universidad Complutense de Madrid, España

Pedro Flores Crespo Universidad Iberoamericana, México

Verónica García Martínez Universidad Juárez Autónoma de Tabasco, México

Francisco F. García Pérez Universidad de Sevilla, España

Edna Luna Serrano Universidad Autónoma de Baja California, México

Alma Maldonado Departamento de Investigaciones Educativas, Centro de Investigación y de Estudios Avanzados, México

Alejandro Márquez Jiménez Instituto de Investigaciones sobre la Universidad y la Educación, UNAM México

José Felipe Martínez Fernández University of California Los Angeles, USA
Fanni Muñoz Pontificia Universidad Católica de Perú

Imanol Ordorika Instituto de Investigaciones Economicas - UNAM, México

Maria Cristina Parra Sandoval Universidad de Zulia, Venezuela

Miguel A. Pereyra Universidad de Granada, España

Monica Pini Universidad Nacional de San Martín, Argentina

Paula Razquin UNESCO, Francia

Ignacio Rivas Flores Universidad de Málaga, España

Daniel Schugurensky Universidad de Toronto-Ontario Institute of Studies in Education, Canadá

Orlando Pulido Chaves Universidad Pedagógica Nacional, Colombia

José Gregorio Rodríguez Universidad Nacional de Colombia

Miriam Rodríguez Vargas Universidad Autónoma de Tamaulipas, México

Mario Rueda Beltrán Instituto de Investigaciones sobre la Universidad y la Educación, UNAM México

José Luis San Fabián Maroto Universidad de Oviedo, España

Yengny Marisol Silva Laya Universidad Iberoamericana, México

Aida Terrón Bañuelos Universidad de Oviedo, España

Jurjo Torres Santomé Universidad de la Coruña, España

Antoni Verger Planells University of Amsterdam, Holanda

Mario Yapu Universidad Para la Investigación Estratégica, Bolivia 


\section{arquivos analíticos de políticas educativas conselho editorial}

Editor: Gustavo E. Fischman (Arizona State University) Editores Associados: Rosa Maria Bueno Fisher e Luis A. Gandin

(Universidade Federal do Rio Grande do Sul)

Dalila Andrade de Oliveira Universidade Federal de Minas Gerais, Brasil

Paulo Carrano Universidade Federal Fluminense, Brasil

Alicia Maria Catalano de Bonamino Pontificia Universidade Católica-Rio, Brasil

Fabiana de Amorim Marcello Universidade Luterana do Brasil, Canoas, Brasil

Alexandre Fernandez Vaz Universidade Federal de Santa Catarina, Brasil

Gaudêncio Frigotto Universidade do Estado do Rio de Janeiro, Brasil

Alfredo M Gomes Universidade Federal de Pernambuco, Brasil

Petronilha Beatriz Gonçalves e Silva Universidade Federal de São Carlos, Brasil

Nadja Herman Pontificia Universidade Católica -Rio Grande do Sul, Brasil

José Machado Pais Instituto de Ciências Sociais da Universidade de Lisboa, Portugal

Wenceslao Machado de Oliveira Jr. Universidade Estadual de Campinas, Brasil
Jefferson Mainardes Universidade Estadual de Ponta Grossa, Brasil

Luciano Mendes de Faria Filho Universidade Federal de Minas Gerais, Brasil

Lia Raquel Moreira Oliveira Universidade do Minho, Portugal

Belmira Oliveira Bueno Universidade de São Paulo, Brasil

António Teodoro Universidade Lusófona, Portugal

Pia L. Wong California State University Sacramento, U.S.A

Sandra Regina Sales Universidade Federal Rural do Rio de Janeiro, Brasil

Elba Siqueira Sá Barreto Fundação Carlos Chagas, Brasil

Manuela Terrasêca Universidade do Porto, Portugal

Robert Verhine Universidade Federal da Bahia, Brasil

Antônio A. S. Zuin Universidade Federal de São Carlos, Brasil 